\title{
MENSTRUAL CAPITALISM, PERIOD POVERTY, AND THE ROLE OF THE B CORPORATION
}

\section{VICTORIA J. HANEMAN*}

Period poverty became the subject of global media attention when it was reported that a schoolgirl used a rolled sock because her mother was unable to afford the purchase of sanitary pads, ${ }^{1}$ thereby focusing attention on the fact that those living in poverty may not be able to cover basic expenses that include shelter, food, and in this instance, hygiene. ${ }^{2}$ In the United States, $41 \%$ of children live in low-income families. ${ }^{3}$ Almost $13 \%$ of women and girls live in poverty (as compared to $11 \%$ of boys and men). ${ }^{4}$ Period poverty is an example of stigma and taboo colliding: The poor are stigmatized and

\footnotetext{
${ }^{*}$ Frank J. Kellegher Professor of Trusts \& Estates, Creighton University School of Law. My heartfelt gratitude to research assistant Sarah K. Mielke for her attention to detail and impressive editing skill.

${ }^{1}$ Daisy Schofield, How period poverty in the UK is preventing girls from going to school, DAZED (Nov. 2019), https://www.dazeddigital.com/life-culture/article/46711/1/period-poverty-uk-preventing-girls-goingschool-absent-film [https://perma.cc/6YBA-NTEZ] (''My mum couldn't give me any products because she didn't get paid until the Friday, and it was a Tuesday ... this meant resorting to a sock wrapped in toilet roll for the first night, until the next day at school, when she informed a teacher who subsequently took her to the nurse. The nurse was able to give a limited supply of pads [and she rationed one a day so that they would last until Friday].”).
}

${ }^{2}$ Ashley Rapp \& Sidonie Kilpatrick, Changing the Cycle: Period Poverty as a Public Health Crisis, THE PuRsuit: TREnding Topics From Mich. Public Health (Feb. 4, 2020), https://sph.umich.edu/pursuit/2020posts/period-poverty.html [https://perma.cc/2NVG-Y4J5] ( defining period poverty as "the prevalent phenomena of being unable to afford products such as pads, tampons, or liners to manage menstrual bleeding. In lieu of sanitary products, many people are forced to use items like rags, paper towels, toilet paper, or cardboard. Others ration sanitary products by using them for extended amounts of time. Period poverty encompasses not only this lack of access to products, but also inadequate access to toilets, handwashing receptacles, and hygienic waste management.").

${ }^{3}$ Heather Koball \& Yang Jiang, Basic Facts about Low-Income Children: Children under 18 Years, 2016, NAT. CTR. FOR CHILD. IN POVERTY (Jan. 2018), https://www.nccp.org/publication/basic-facts-about-lowincome-children-children-under-18-years-

2016/\#: : :text=How\%20many\%20children\%20under\%20age,families\%20in\%20the\%20United\%20States\%3 F\&text=There $\% 20$ are $\% 2072.4 \% 20$ million $\% 20$ children,live $\% 20$ in $\% 201$ low $\% 2$ Dincome $\% 20$ families [https://perma.cc/V9LV-46MD].

${ }^{4}$ Robin Bleiweis et al., The Basic Facts About Women in Poverty, CTR. FOR Am. Progress (Aug. 2020), https://www.americanprogress.org/issues/women/reports/2020/08/03/488536/basic-facts-women-poverty/ [https://perma.cc/K8HZ-QDX4] (noting that in 2018, 12.9\% of females were poor as compared to $10.6 \%$ of men). 
menstruation is taboo. The law imposes rules that reinforce taboo around basic biological processes such as birth, ${ }^{5}$ death, ${ }^{6}$ and sex. ${ }^{7}$ To the extent that a taboo constrains individual autonomy, it also impacts economic choice - shaping and limiting options for women and also deriving profit at the expense of women. ${ }^{8}$ The white patriarchy has spent the past century stigmatizing, co-opting, and then reshaping spaces that either seriously impact or involve women, and turning deeply personal organic life moments for women into highly profitable capitalist markets.

A menstruation industrial complex has arisen to commercialize the monthly clean-up of uterine waste, and it is interesting to consider the ways in which period poverty and menstrual capitalism ${ }^{9}$ are opposite sides of the same coin. Given that the average woman will dispose of 250 to 300 pounds of "pads, plugs, and applicators" 10 in her lifetime and menstruate for an average of thirty-eight years, ${ }^{11}$ this is a marketplace with substantial

\footnotetext{
${ }^{5}$ See Cece Bobbitt, A Platform of Her Own: An Examination of Feminist Attempts to Reclaim Pregnancy from Medicalized Gynecology, VAsSAR Coll. Senior CAPSTONe Projects (2019),

https://digitalwindow.vassar.edu/cgi/viewcontent.cgi?article=1913\&context=senior_capstone [https://perma.cc/JXZ7-A8LH].
}

${ }^{6}$ See Tanya D. Marsh, Regulated to Death: Occupational Licensing and the Demise of the U.S. Funeral Services Industry, 8 WAKE FOREST J.L. \& POL'y 5, 6-7 (2018).

${ }^{7}$ Taboo is a term of Polynesian origin, introduced to the English language in the $18^{\text {th }}$ Century, defined as "the prohibition of an action based on the belief that such behaviour is either too sacred and consecrated or too dangerous and accursed for ordinary individuals to undertake." Chaim Fershtam et al., Taboos and Identity: Considering the Unthinkable, 3 Am. Econ. J.: Microeonomics 139, 139-42 (2011).

${ }^{8}$ This practice is sometimes referred to as the "Wellness Industrial Complex." Dr. Jen Gunter on "Vagina Profiteers: The Economics of the Wellness Industrial Complex", GENDER \& THE ECON. (Oct. 29, 2019), https://www.gendereconomy.org/dr-jen-gunter/[https://perma.cc/95KY-E8GV] (explaining that "the wellness industrial complex is partly based on 'vaginal shame': society perceives women's bodies and bodily functions as disgusting, toxic, or unclean.").

${ }^{9}$ Professor Bridget Crawford has coined the term "menstrual capitalism," which she has defined as "the marketing and selling of menstrual hygiene products by means of feminist messages that attempt to create a public-relations 'halo effect." 'See Bridget Crawford, Against Menstrual Capitalism, Feminist L.

PROFESSORS (June 25, 2018), https://www.feministlawprofessors.com/2018/06/against-menstrual-capitalism/ [https://perma.cc/8JTX-J7X4] [hereinafter Crawford, Against Menstrual Capitalism].

${ }^{10}$ Nina Shen Rastogi, Greening the Crimson Tide: What's the environmental impact of my period?, SLATE (Mar. 16, 2010), https://slate.com/technology/2010/03/what-s-the-environmental-impact-of-my-period.html [https://perma.cc/CNC9-LKS7].

${ }^{11}$ It is important to acknowledge at the outset that not all who menstruate are women and not all women menstruate. See, e.g., Yasmin Jeffery, Women aren't the only ones who menstruate. This is why the Period 
profit to be reaped even from the marginalized poor. ${ }^{12}$ As consciousness of issues such as period poverty and structural gender inequality increases, menstruation marketing has evolved and gradually started to "go woke" through messaging that may not be genuine. ${ }^{13}$ Companies are profit-seeking and the woke-washing of advertising, or messaging designed to appeal to progressively-oriented sentimentality, is a legitimate concern. ${ }^{14}$ Authenticity matters to those consumers who would like to distinguish genuine brand activism from an appropriating marketing device, but few objective approaches are available to assess authentic commitment.

This Essay considers the profit to be made in virtue signaling solely for the purpose of attracting customers and driving sales: Pro-female, woke menstruation messaging that may merely be an exploitative and empty co-optation. Feminists should expect more of menstrual capitalists, including a commitment that firms operating within this space address the diapositive issue of period poverty and meaningfully assist those unable to meet basic hygiene needs who may never be direct consumers. This Essay serves as a thought piece that first presents, in Section I, the B Corporation as a relatively new direction in corporate law that redefines the corporation as a potential agent of social change. Section II considers the way in which B Corporation certification may serve as an implicit sorting device to distinguish companies performing hollow virtue signaling from those menstrual capitalists committed to socially responsible pro-female business practices.

Pack movement is using inclusive language, ABC NEws (Feb. 24, 2020), https://www.abc.net.au/news/202002-25/menstruation-trans-people-how-fix-stigma-period-pack-abc-heywire/11971616

[https://perma.cc/87N2-TKQ5] (highlighting the "ripple of resistance to the ides of providing period products to people of all genders").

${ }^{12}$ See Crawford, Against Menstrual Capitalism, supra note 10.

${ }^{13}$ Abigail Radnor, 'We're having menstrual liberation': how periods got woke, THE GUARDIAN (Nov. 11, 2017), https://www.theguardian.com/society/2017/nov/11/periods-menstruation-liberation-women-activistsabigail-radnor [https://perma.cc/HRG8-7XXC].

${ }^{14}$ Owen Jones, Woke-Washing: how brands are cashing in on the culture wars, THE GUARDIAN (May 23, 2019), https://www.theguardian.com/media/2019/may/23/woke-washing-brands-cashing-in-on-culture-warsowen-jones [https://perma.cc/V9J6-K25P]. 


\section{The B Corp to Facilitate Reappropriation}

The term "greenwashing" was coined in 1986 to refer to companies that exaggerate a commitment to the environment, ${ }^{15}$ "faux CSR" was coined in 2011 to refer to firms that misrepresent a commitment to social responsibility, ${ }^{16}$ and most recently, "woke washing" has come to refer to appropriating language of social activism into marketing campaigns. ${ }^{17}$ We see, manifested through language, more than three decades of concern that progressive marketing campaigns are empty words. One study estimates that women control $70 \%$ to $80 \%$ of all consumer purchasing. ${ }^{18}$ Counterhegemonic marketing tactics may drive profit, but if not authentic, they are commoditizing feminism in a way that is base, appropriating, and exploitative.

Consumers have reason to be wary about misleading "femvertism" related to the marketing of menstrual products - or the exploitation of feminism simply to sell products. "Slacktivism" or low-effort activism will exploit a cause only for marketing purposes or production value, but the company itself takes no action to support the cause. ${ }^{19}$ It is supporting a cause in a performative or minimally burdensome (and likely minimally productive) way. Problematically, the advertising industry has exploited rather than empowered women for decades. Marketing campaigns carry diagnostic value for a consumer: Attribution research suggests that when a consumer learns about the behavior of a firm about which they have little information, they tend to take the behavior at face

\footnotetext{
${ }^{15}$ Bruce Watson, The troubling evolution of corporate greenwashing, THE GUARDIAN (Aug. 20, 2016), https://www.theguardian.com/sustainable-business/2016/aug/20/greenwashing-environmentalism-liescompanies [https://perma.cc/X59A-FMTQ].

${ }^{16}$ Miriam A. Cherry \& Judd F. Sneirson, Beyond Profit: Rethinking Corporate Social Responsibility and Greenwashing After the BP Oil Disaster, 85 TuL. L. REv. 983, 985-86 (2011) (referring to faux corporate social responsibility).

${ }^{17}$ Erin Dowell \& Marlette Jackson, “Woke-Washing” Your Company Won't Cut It, Harv. Bus. Rev. (July 27, 2020), https://hbr.org/2020/07/woke-washing-your-company-wont-cut-it [https://perma.cc/WS5H-BR57].

${ }^{18}$ Amy Nelson, Women Drive Majority of Consumer Purchasing and It's Time to Meet Their Needs, InC. (July 17, 2019), https://www.inc.com/amy-nelson/women-drive-majority-of-consumer-purchasing-its-timeto-meet-their-needs.html [https://perma.cc/82MZ-KMNK].

${ }^{19}$ Katie Anderton, 'Femvertising' is Exploiting Feminism, Medium (Aug. 20, 2020), https://medium.com/fearless-she-wrote/femvertising-is-exploiting-feminism-f3addc174eee [https://perma.cc/WFB7-DBLV].
} 
value. ${ }^{20}$ Slacktivism is troubling in that it should not carry diagnostic or informational value for the consumer, and yet likely does.

Studies also suggest that a genuine business commitment to a social purpose requires "a substantial change in the business model." 21 To that end, we consider the B Corp-a certification for businesses that have decided to focus on purpose alongside profit - and the use of B Corp certification as an important consumer signaling device to identify some verified level of sincerity.

While benefit and public benefit corporations are U.S. state-legislated corporate entities, B Corp status refers to a certification awarded by a 501(c) U.S. non-profit organization called B Lab. B Corps are companies that have chosen to participate in an exhaustive auditing process wherein B Lab attempts to verify and measure a business's "current impact" through a comprehensive rating system. ${ }^{22}$ The B Impact Score is a company-level rating for certified B corps that includes targeted sub-ratings in categories such as governance, workers, community, and environment. ${ }^{23}$ The result of this scoring process is a publicly accessible B Impact Report. Annual certification fees may range from $\$ 1,000$ to $\$ 50,000$, and a firm must be recertified every three years. ${ }^{24}$ Any firm that is formed in a state that recognizes benefit or public benefit corporations must elect this status within a few years to retain B Corp certification, ${ }^{25}$ but benefit corporations (as a

\footnotetext{
${ }^{20}$ Yeosun Yoon et al., The Effect of Corporate Social Responsibility (CSR) Activities on Companies with Bad Reputations, 16 J. CONSUMER PsYCH. 377, 377-82 (2006) (reporting that among consumers studied, "CSR activity backfired when consumers had reason to doubt the company's motives, namely, when the company supported a cause with high benefit salience").

${ }^{21}$ See Elisabeth Paulet \& Francesc Relano, Differentiating between Sincere and Insincere Corporate Social Responsibility (CSR): Evidence from the German Banking Industry, 552 SAFE BANK 65, 65-84 (2014) (reaching this conclusion in the context of the banking industry).

${ }^{22}$ Frequently Asked Questions: Top 10, B IMPACT AsSESSMENT, https://bimpactassessment.net/how-itworks/frequently-asked-questions/top-10\#how-does-this-relate-to-other-impact-measurement-systems [https://perma.cc/2VVQ-FTLH] .

${ }^{23}$ Frequently Asked Questions: The B Impact Score, B IMPACT AsSESSMENT, https://bimpactassessment.net/how-it-works/frequently-asked-questions/the-b-impact-score [https://perma.cc/ES4L-D8DK].

${ }^{24}$ Certification, CERTIFIED B CORPORATION, https://bcorporation.net/certification [https://perma.cc/QWT6J2LG].

${ }^{25}$ The publicly traded Laureate Education is an example of a firm that is both a benefits corporation and a Certified B Corporation. Maria Stracqualursi, The Rise of the Public Benefit Corporation: Considerations for
} 
legal entity) are not generally held to the rigorous standards met through B Corp certification. ${ }^{26}$ Criticism of B Lab's certification process concerns the fact that B Lab is a private organization establishing its own standards, and there is not necessarily full transparency built into the certification process itself. ${ }^{27}$ Further, any time a certified B Corp wishes to walk away from certification, for whatever reason, they may do so (e.g., Etsy) and no list is made publicly available of those who have chosen decertification. ${ }^{28} \mathrm{~A}$ recent study suggests that as many as $34 \%$ of successfully certified B Corps have chosen decertification. $^{29}$

The B Corp movement is gaining traction globally, with now more than 3,500 B Corps worldwide. ${ }^{30}$ Since the pandemic summer of 2020, two more B Corps have gone public and six large multinationals are starting the process to qualify for certification. ${ }^{31}$ Mainstream venture capital firms are investing in B Corps, and some venture capital firms themselves have become certified B Corps. ${ }^{32}$ To be sure, the B Corp certification process is labor and cost intensive-requiring transparency and continual impact assessments, with substantial outcomes articulated and an evaluative process to assess

Start-ups, Bos. Coll. LegAl Servs. LAB (Mar. 21, 2017), http://bclawlab.org/eicblog/2017/3/21/the-rise-ofthe-public-benefit-corporation-considerations-for-start-ups [https://perma.cc/SM2W-5KWU].

${ }^{26}$ See Michelle Cho, Benefit Corporations in the United States and Community Interest Companies in the United Kingdom: Does Social Enterprise Actually Work?, 37 Nw. J. INT'L L. \& Bus. 149, 156-57 ( 2016) (noting two criticisms of benefit corporations: lack of accountability in the statute and lack of oversight by directors).

27 See Michael O'Regan, B Corp certification won't guarantee companies really care for people, planet and profit, THE CONVERSATION (Oct. 7, 2019), https://theconversation.com/b-corp-certification-wont-guaranteecompanies-really-care-for-people-planet-and-profit-124459 [https://perma.cc/3AFR-NS5E].

${ }^{28} I d$.

${ }^{29}$ Peter W. Moroz et al., Imprinting with purpose: Prosocial opportunities and B Corp certification, 33 Journal of Bus. Venturing 117, 124 (2018) (citing Xiujian Chen \& Thomas F. Kelly, B-Corps-A Growing Form of Social Enterprise: Tracing Their Progress and Assessing Their Performance, $22 \mathrm{~J}$. LEADERSHIP \& ORG. STUD. 102 (2014)).

${ }^{30}$ Talib Visram, How the B Corporation movement is remaking business, FAst Co. (Oct. 8, 2020), https://www.fastcompany.com/90560758/how-the-b-corp-movement-is-remaking-business [https://perma.cc/Y7MU-JKNE].

${ }^{31}$ Vital Farms and Lemonade have gone public. Id.

${ }^{32}$ Real estate investor Fifth Wall and tech investor Foundry Group have become certified B corporations. Id. 
performance against those outcomes. ${ }^{33}$ In other words, B Corporation certification requires a demonstrated commitment to accountability and transparency that the insincere would be unlikely to embrace. ${ }^{34}$ It has said that B Corps are a "a needed reboot for capitalism for the modern age, ensuring that the social responsibility of business is not only about profits, but also contributing solutions to the world's most pressing problems." ${ }^{35}$

\section{Mediating the Intersection of Menstruation and Capitalism}

The social movements to address menstrual equity and period poverty do not exist in isolation - nor do they need to exist in opposition to capitalism. Feminism existing within a neoliberal framework necessarily employs marketing campaigns with pro-women messaging. An exogenous professional third-party regulatory entity (the non-profit B Lab regulating through the $\mathrm{B}$ Corporation certification) has played a perhaps heretofore unrecognized role as a social movement actor, allowing firms to shift away from the primacy of shareholder value maximization and to submit their practices and strategies to be vetted for authenticity. ${ }^{36}$

We often fail to recognize the gendered and racialized power dynamic that is expressed through corporate law. ${ }^{37}$ There has historically been an erasure of those who are not white and male through corporate policies. ${ }^{38}$ Scholars critical of B Corporations

\footnotetext{
${ }^{33}$ See Certification Requirements, CERTIFIED B CORPORATION, https://bcorporation.net/certification/meet-therequirements [https://perma.cc/HKC9-RQEY] (noting that the review process can take between six to ten months);- Darian Kovacs, Five Things You Should Know Before Becoming A Certified B Corporation, FORBES, https://www.forbes.com/sites/forbesagencycouncil/2019/07/08/five-things-you-should-know-beforebecoming-a-certified-b-corporation/?sh=56474de34f5b [https://perma.cc/7VWZ-LCJV].

${ }^{34}$ See supra note 24.

${ }^{35}$ Footwear company Dansko became a B corporation as a way of helping the firm to measure its environmental footprint. Richard Stammer, It Pays to Become a B Corporation, HARV. Bus. Rev. (Dec. 6, 2016), https://hbr.org/2016/12/it-pays-to-become-a-b-corporation [https://perma.cc/7RZ7-TST2].

${ }^{36}$ Frank Dobbin \& Jiwook Jung, Professions, Social Movements, and the Sovereign Nation, in PLAYERS AND Arenas: The Interactive Dynamics of Protest 141, 168 (James M. Jasper \& Jan Willem Duyvendak eds., 2015).

${ }^{37}$ See, e.g., Sarah C. Haan, Corporate Governance and the Feminization of Capital, SSRN (Dec. 1, 2020), https://papers.ssrn.com/sol3/papers.cfm?abstract_id=3740608 [https://perma.cc/HNE6-Y2NY].]

${ }^{38} I d$.
} 
fail to recognize the need for historically marginalized groups to know that modern corporate action is genuine - and that we are not simply being conned. Sincerity matters.

The first B Corporations were certified in 2007, with the process gradually gaining traction. ${ }^{39}$ The effectiveness of B Corp certification remains to be seen and has not yet been extensively studied - it is a market differentiator that is too new. ${ }^{40}$ Businesses that have wanted to deprioritize profit maximization are, it is argued, already in a position to do so. To the extent to which businesses are guided by norms, however, B Corp certification normalizes doing so. For an existing business, B Corp certification often requires a wholesale destruction and reconstruction of the organization to reshape its identity. This type of change is both bottom-up and top-down, impacting everyday work as well as long-term goals. It is a deliberate choice that shapes internal norms and culture, as well as the overarching ethos of the business. Put simply, a commitment to a set of stated progressive values is more than a marketing gambit for a certified B Corp. Early research suggests that the B Corp certification process may be invaluable as a marketplace differentiator for entrepreneurs who have "no other means to socially validate their beliefs and identities." ${ }^{41}$ This certification process brings transparency to alignment with mission.

Market-driven certification offers a potential solution for certain market-produced problems. First, for those who have historically been exploited or erased through marketing, authenticity and sincerity are important. Second, menstrual-aware advertisement continues to market feminine care products that are luxury items for many. The shameful truth is that period poverty is one of the most easily solved but rarely discussed public health crises of our time. One out of five American girls miss school because of inadequate access to menstrual products, and sometimes those without access to menstrual supplies drop out of school entirely. ${ }^{42}$ Important supplemental programs designed to help those struggling in the United States, such as WIC (the Special

\footnotetext{
${ }^{39}$ What You Ought to Know About Certified B Corps, Cultivating CAP., https://www.cultivatingcapital.com/b-corporation/ [https://perma.cc/R5WA-QBGT] .

${ }^{40}$ Ronald J. Colombo, Taking Stock of the Benefit Corporation, 7 TEX. A\&M L. REv. 73, 100-02 (2019).

${ }^{41}$ See Moroz, supra note 30, at 126.

${ }^{42}$ Ashely Rapp \& Sidonie Kilpatrick, Changing the Cycle: Period Poverty as a Public Health Crisis, UnIV. OF Mich. Sch. OF Pub. Health (Feb. 4, 2020), https://sph.umich.edu/pursuit/2020posts/period-poverty.html [https://perma.cc/R3DN-KZ8Y]; Kassia Binkowski, Ending of Period Poverty: Interview with Molly Hayward, Founder of Cora, THE GoOD TRADE, https://www.thegoodtrade.com/features/interview-seriesmolly-hayward-founder-of-cora [https://perma.cc/E96E-NMQ].
} 
Supplemental Nutrition Program for Women, Infants, and Children) and SNAP (Supplemental Nutrition Assistance Program), do not cover menstrual products. ${ }^{43}$

The mission, goals, and accomplishments of those menstrual capitalists vary dramatically, not always including period poverty, but the transparency of B Corps empowers the consumer. By way of example, a number of firms have noteworthy social goals (including environmental sustainability), but do not focus on period poverty: GladRags (impact score 100.5) has a general focus upon the creation of reusable menstrual products and sustainable practices; ${ }^{44}$ Yoni (impact score 80.0 ) is leading "a bloody revolution in the fem care industry," with the important goal of educating women about the ingredients in menstrual products. ${ }^{45}$ The availability of information allows the consumer to easily find and support those B Corps that have a stated, demonstrated, and verified commitment to tackling period poverty specifically. Cora (impact score 105.1) (6 $^{46}$ creates natural tampons and pads and partners with other global organizations to combat period poverty_providing a month's supply of pads to a girl in need for each month's supply purchased, with more than a million pads donated so far. ${ }^{47}$ Aisle (formerly Lunapads, impact score 117.3) ${ }^{48}$ manufactures trans-inclusive and sustainable menstrual care products, and has a global mission to provide access to products through its organization Pads for Girls, which has aided 17,000 menstruators in eighteen countries. ${ }^{49}$ Dame (impact score 88.6$)^{50}$ is troubled by the environmentally toxic nature of the

\footnotetext{
${ }^{43}$ Rebecca Alwine, Menstrual Care Products Aren't Governed by SNAP Benefits, ESME, https://esme.com/resources/public-assistance/help-single-moms-afford-menstrual-care-products-snap-benefits [https://perma.cc/Q4FV-9PQU].

${ }^{44}$ GladRags, B IMPACT REP., https://bcorporation.net/directory/gladrags [https://perma.cc/9WE8-GZHL].

${ }^{45}$ Yoni, B IMPACT ReP., https://bcorporation.net/directory/yoni [https://perma.cc/C5MK-4F7A].

${ }^{46}$ Lyv Life Inc., B IMPACT REP., https://bcorporation.net/directory/lyv-life-inc [https://perma.cc/6CVH$\mathrm{H} 5 \mathrm{XK}]$.

${ }^{47}$ Supra note 36. Tara McMullin, Disrupting a Very Old Market with Cora Co-Founder Molly Hayward, TARA MCMULLIN, http://taragentile.com/disrupting-old-market-molly-hayward/ [https://perma.cc/S6ZRM4KL].

${ }^{48}$ Aisle, B IMPACT REP., https://bcorporation.net/directory/aisle [https://perma.cc/WPS8-HZP9].

${ }^{49}$ Keeley Griego, 5 Companies Fighting Period Poverty, Borgen Mag. (Aug. 19, 2019), https://www.borgenmagazine.com/companies-fighting-period-poverty/ [https://perma.cc/2Y84-V99A].

${ }^{50}$ DAME, B IMPACT REP., https://bcorporation.uk/directory/dame [https://perma.cc/76QS-FY7D].
} 
menstrual product industry and has a similarly green mission. ${ }^{51}$ In addition, accessibility to products is part of its mission, and its Impact Report notes that they engaged in lobbying efforts and donated products to Rethink Periods. ${ }^{52}$ DivaCup (impact score 98.7) has a transparent mission: "Having access to safe period care is a basic human right, and we are working to normalize this dialogue and put words into action. Period poverty has no restrictions - it's experienced from within our neighborhoods to a global scale." ${ }^{\text {"T3 }}$ This is L, Inc. (impact score 86.0) makes natural menstrual products and gives one product to a person in need for every product sold. ${ }^{54}$ Dignity (impact score 85.6) has a similar "buy one, give one" model. ${ }^{55}$ Saalt (impact score 93.3 ) ${ }^{56}$ has donated more than 7,117 menstrual cups. ${ }^{57}$

It is important to note that some traditional $\mathrm{C}$ Corporations in corporate America have taken a similar interest in period poverty initiatives. Walmart teamed with Procter \& Gamble's Always to donate a year's worth of menstrual products to fifty local extracurricular organizations. A video uploaded to YouTube showcases young girls in a martial arts studio who received Always pads. For one month in 2019, for every threepack box of Always pads purchased on Walmart.com, the merchant donated a three-pack box. Despite such efforts, the cynical question lurks of whether this is authentic social action or corporate virtue signaling. At odds with the desire of Always to paint itself as a period poverty crusader is the fact that its customers in Kenya discovered that the Always low-priced pads in Kenya (\$0.50 a pack in a country where $37 \%$ of the population makes

${ }^{51} I d$.

52 Impact Report 2020, DAME, https://wearedame.co/pages/impact-report [https://perma.cc/KP2Y-CUS7] (last visited Dec. 27, 2020).

${ }^{53}$ DivaCares-Where Passion Meets Programming, DivaCup (Jun. 4, 2019), https://divacup.com/divacareswhere-passion-meets-programming/ [https://perma.cc/CML2-HTRF].

${ }^{54}$ This is L. Inc., B IMPACT REP., https://bcorporation.net/directory/l-inc [https://perma.cc/WGR5-SC2H] (last visited Dec. 27, 2020).

${ }^{55}$ Dignity, B IMPACT ReP., https://bcorporation.net/directory/dignity [https://perma.cc/65RC-J6T4] (last visited Dec. 27, 2020).

${ }^{56}$ Saalt, LLC, B IMPACT REP. (DEC. 27, 2020), https://bcorporation.net/directory/saalt-llc [https://perma.cc/NJ9H-CPGH].]

${ }^{57}$ This information is available on pages 2-3 in the Impact Report published on the business website. SAALT, https://saalt.com/pages/impact [https://perma.cc/7W7D-CBMW] (last visited Dec. 27, 2020). 
less than $\$ 1.25$ a day) frequently caused burns, skin eruptions, and contact dermatitis. ${ }^{58}$ Always has never accepted responsibility for selling a less expensive and perhaps problematic product in developing countries, but did produce an advertisement addressing the Twitter campaign that is regarded as insincere and troubling. ${ }^{59}$

Will shoppers use information (i.e., company mission, B Corp certification, etc.) to leverage the power of consumer spending? Many scholars believe that the most common form of political action other than voting is consumer spending ${ }^{60}$ and social movements (or "intentional collective efforts ... to transform social order") should not overlook the transformative role of the consumer to vote with their proverbial wallets. ${ }^{61}$ In fact, many activists believe that buycotting — or showing support for a brand or company through the purchase of products - is far more effective than boycotting. ${ }^{62}$ PR specialists have suggested that the buycott will be the powerful consumer activist movement of the future, with buycotters skewing younger, leaning on social media for the wide dissemination of information, and generally having less faith in the power of the boycott. ${ }^{63}$ Interestingly, the demographics of the consumer advocate or critical consumer are skewed towards the

\footnotetext{
${ }^{58}$ Ciku Kimeria, The story of how Kenyan women are bringing $P \& G$ to task over the Always "burning pads" saga, QUARTZ AFR. (Feb. 26, 2020), https://qz.com/africa/1807045/kenyan-women-take-pg-to-task-overalways-burning-pads/ [https://perma.cc/G4HQ-TD4E] (noting the Twitter hashtag \#myalwaysexperience).

${ }^{59}$ Dr. Bridget Bema (@njokingumi), TwitTer (Jan. 22, 2020), https://twitter.com/njokingumi/status/1220206723484585984?lang=en [https://perma.cc/9ZMS-LR3E] (referring to the ad as "perplexing, Feminism Lite 'activism' cosplay ....").

${ }^{60}$ Consumer Activism: A Growing Threat to Corporate Reputation, COMMETRIC (Nov. 29, 2019), https://commetric.com/2019/11/29/consumer-activism-a-growing-threat-to-corporate-reputation/ [https://perma.cc/D8JH-CZA6].

${ }^{61}$ See Robert V. Kozinets \& Jay M. Handelman, Adversaries of Consumption: Consumer Movements, Activism and Ideology, 31 J. CONSUMER RSCH. 691, 700 (2004) (underscoring the power of consumers, stating "[c]onsumers are the linchpin in the social change activists seek and thus ineluctably also the things that stand in the way of this change.").

${ }^{62}$ Weber Shandwick, Rising Consumer Activist Movement Emerges to Support Companies and Their Reputations, Cision (Jan. 31, 2018), https://www.prnewswire.com/news-releases/rising-consumer-activistmovement-emerges-to-support-companies-and-their-reputations-300591105.html [https://perma.cc/XM8RJEUU].

${ }^{63} \mathrm{Id}$.
} 
two most popular demographics for marketers of menstrual products: women (56 percent) and the youngest generations ( $41 \%$ Millennials and Generation Z) ${ }^{64}$

B Corp certification has passed the proof of concept stage, and though still early stage, the financial benefits have been impossible to ignore. Sustainable and responsible investments are outperforming peers, ${ }^{65}$ and investors who previously said that they would "run screaming from a B Corp" are now investing capital in them. ${ }^{66}$ More than 3,300 B Corps are certified across seventy countries and 150 industries, with numbers growing almost exponentially. ${ }^{67}$ And though initial success of the B Corp certification requires further study, early studies support the notion that ethical, regenerative businesses that respond to social inequities and injustices appeal to the consumer. The activist consumer should not have to take empty marketing messaging at face value, and $\mathrm{B}$ certification may provide a metric of do-goodery and trustworthiness that has the potential to be revolutionary in the world of business.

\section{CONCLUSION}

The visionaries of the $\mathrm{C}$-suite are those leaders who anticipate (rather than merely respond to) market change, or in this case, the zeitgeist of the Millennial and Generation $\mathrm{Z}$ consumer. These two generations are more embracing of socialism and distrustful of

\footnotetext{
${ }^{64}$ Jena Mcgregor, Why 'Buycotts' could overtake boycotts among consumer activists, WASH. POST (Feb. 28, 2018), https://www.washingtonpost.com/news/on-leadership/wp/2018/02/28/why-buycotts-could-overtakeboycotts-among-consumer-activists/ [https://perma.cc/9UFP-PYQS].

65 " [A] sset management bellwether BlackRock shows that investment funds tracking the performance of corporations considered to be more committed to environmental, social and governance (ESG) issues have fared better than others so far during the COVID-19 crisis." Josie Cox, Resilience In Crisis: Coronavirus Reveals Why Businesses Must Do Good to Do Well, ForBes (Jun. 8, 2020), https://www.forbes.com/sites/josiecox/2020/06/08/climate-crisis-coronavirus-b-corp-business-esg-do-goodto-do-well/?sh=a26a44b55782 [https://perma.cc/6G2P-VSTP].

${ }^{66}$ Michael O'Leary \& Warren Vladmanis, Challenging the Trade-off Mentality, STAN. Soc. InNOvation REV. (Dec. 15, 2020), https://ssir.org/books/excerpts/entry/challenging_the_trade_off_mentality [https://perma.cc/J3CK-2VKB].

${ }^{67}$ B Lab Honored as a 2020 World's Most Innovative Company by Fast Company, CERTIFIED B CORPORATION (March 10, 2020), https://bcorporation.net/news/worlds-most-innovative-company-fastcompany-2020 [https://perma.cc/A3XN-NQNR]. Supra note 58.
} 
their fellow citizens and government than preceding generations. ${ }^{68}$ As the increasing significance of America's youngest generations of consumer collides with global turmoil wrought by the COVID-19 pandemic, it is no surprise that there has been a surge of interest in B Corporation certification. ${ }^{69}$ Out of crisis comes the opportunity to innovate around traditional models, and B Corporation certification encourages the dismantling of structures that disadvantage marginalized groups - with an emphasis on aligning business with social mission and a commitment to transparency. The insincere would not willingly submit themselves to the organizational accountability and transparency that comes with benefit corporation status or B Corp certification. This Essay is a thought piece that hints at the transformative potential of B Corp certification as a consumer education device that, applied in the context of menstrual capitalism, signals the authenticity of pro-women progressive messaging.

${ }^{68}$ Eric Levitz, America's Most Socialist Generation Is Also The Most Misanthropic, INTELLIGENCER (Aug. 15, 2019), https://nymag.com/intelligencer/2019/08/polls-millennials-and-gen-zers-are-dystopiansocialists.html [https://perma.cc/9FVN-ASCT].

${ }^{69}$ Mckenna Moore, The B Corp movement is accelerating during the pandemic, ForTUNE (July 7, 2020), https://fortune.com/2020/07/07/danone-emmanuel-faber-b-corp-movement/ [https://perma.cc/V269-YAL7]. 